Original Article

\title{
INDUCTION OF CASPASE-3 DEPENDENT APOPTOSIS, CELL CYCLE ARREST AND CYTOTOXICITY IN BREAST CANCER CELLS BY ABRUS PRECATORIUS
}

\author{
MOHAMMED SHAFI SOFI' ${ }^{1}$, SHABNUM NABI ${ }^{2}$ \\ ${ }^{1}$ Molecular Diagnostics and Nanobiotechnology Laboratories, Department of Microbiology and Biotechnology, Bangalore University, J. B. \\ Campus, Bangalore, Karnataka, India, ${ }^{2}$ Interdisciplinary Brain Research Centre, Jawaharlal Nehru Medical College, Aligarh Muslim \\ University, Aligarh, U. P. \\ Email: mshafi.sofii@gmail.com
}

Received: 18 Feb 2017 Revised and Accepted: 27 Jun 2018

\begin{abstract}
Objective: To evaluate the leaf extract of Abrus precatorius as a potential therapy for breast cancer treatment.

Methods: Aqueous leaf extracts of A. precatorius was prepared by the process of maceration. The collected filtrate was further partitioned successively into five solvent fractions starting from water, hexane, chloroform, ethyl acetate and butanol by solvent fractionation method using separating funnel. Finally, all the five fractions were subjected to cytotoxic activity assay. The molecular mechanism underlying cytotoxicity was determined by using various approaches viz., 3-(4,5-dimethylthiazol-2-yl)-2,5-diphenyltetrazolium bromide (MTT) assay, Fluorescence-activated cell sorting (FACS) analysis, Western blot analysis, casp-glow assay and Semi-quantitative reverse transcription polymerase chain reaction (RTPCR) analysis.
\end{abstract}

Results: Among five fractions only ethyl acetate fraction of A. precatorius (EAF-AP) showed significant cytotoxic activity on MDA-MB-231 cells, with an IC 50 value of $47.3 \mu \mathrm{g} / \mathrm{ml}$. Apoptosis was confirmed by the appearance of Sub G0/G1 (apoptotic) peak by FACS analysis. Western blotting results clearly indicated cleavage of Caspase-3 and PARP. Casp-glow assay confirmed activation of caspase-3, an important mediator of apoptosis. Semiquantitative RT-PCR analysis showed an up-regulation of pro-apoptotic genes (p21, p53 and Bax) and down-regulation of the anti-apoptotic Bcl-2 gene, which is an important hallmark of an apoptosis.

Conclusion: All these results indicate that EAF-AP, induced apoptosis in MDA-MB-231 cells, making A. precatorius a potentially good candidate for anticancer drug development.

Keywords: Abrus precatorius L., Cytotoxicity, Breast cancer cells, Apoptosis

(c) 2018 The Authors. Published by Innovare Academic Sciences Pvt Ltd. This is an open access article under the CC BY license (http://creativecommons.org/licenses/by/4.0/) DOI: http://dx.doi.org/10.22159/ijpps.2018v10i8.17996

\section{INTRODUCTION}

Cancer is a multifaceted devastating disease that arises as a result of a multistep process called carcinogenesis affecting millions of people per year and poses both economic and psychological challenges [13]. It is a major public health problem that continues to be a second leading cause of death in humans all over the world. It has been reported around 14.1 million people were detected with cancer and 8.2 million people died from cancer [4]. Precisely, by 2025 nearly $80 \%$ of an increase in the number of all cancer deaths will occur in developing regions of the world and reach close to 25 million over the next two decades [5]. Among cancer, breast cancer (malignant breast neoplasm) is the most frequently diagnosed disease and second leading cause of cancer-related deaths in women [6]. Worldwide breast cancer mortality among females was $23 \%(1.38$ million) of the total new cancer cases and $14 \%(458,400)$ of the total cancer deceases recorded in 2008 [7].

Despite significant advances toward targeted therapy and screening techniques, breast cancer cells subsequently survive and gain resistance to the treatment [8]. Thus, identification and characterization of novel agents that are relatively safe and can suppress the growth of metastatic human breast cancers is highly desirable. In recent years, there has been growing interest in alternative therapies and therapeutic use of natural products; especially those derived from plants [9]. Many chemotherapeutic agents currently in clinical use have originated from plants or are analogs of plant-derived compounds [10]. Over $60 \%$ of the current anticancer drugs have their origin in one way or another from natural sources $[11,12]$. Medicinal plant-derived compounds have played an important role in the development of several clinically useful anticancer agents. Anticancer properties of these compounds include regulation of cancer-associated gene expression, inhibition of enzyme activity, induction of apoptosis or cell cycle arrest [14].
Abrus precatorius which is commonly known as Indian liquorice, rosary pea, jequirity bean belongs to the family Leguminosae (Fabaceae). Its seeds, roots, vines and leaves have been used as a folk medicine since ancient times [15]. The leaf is commonly chewed or sucked to obtain its sweet taste and is also used traditionally for the treatment of various health issues [16, 17]. Many previous studies have shown that $A$. precatorius has several biologically active molecules that show effective cytotoxic activity against various cancer cell lines [18-20]. So far the emphasis has been given to the seed extracts; whereas very few studies have been carried out to evaluate the anticancer potential of leaf extracts. A thorough scientific screening of $A$. precatorius for its anticancer properties has not been reported. Hence in the present study, the leaves of $A$. precatorius were fractionated into various solvent systems, in order to isolate the maximum number of cytotoxic compounds. Therefore, efforts were made for isolating and identifying the key anticancer molecules present in A. precatorius leaves and to further confirm an exact molecular mechanism behind the cytotoxic and apoptotic effect of $A$. precatorius on MDA-MB-231 breast cancer cells.

\section{MATERIALS AND METHODS}

\section{Reagents and chemicals}

MTT reagent (Sigma, St. Louis, MO, USA), Propidium Iodide (Invitrogen, New York, NY, USA), Caspase-3 and PARP antibody, Caspase-Glow assay Kit (Promega Corporation, Madison WI, USA), RNAse (Sigma, St. Louis, MO, USA), proteinase K (Sigma, St. Louis, MO, USA), ethidium bromide (Invitrogen, New York, USA), Reverse Transcription kit (Applied Biosystems, Inc., California, San Francisco), protease inhibitor cocktail (Calbiochem), polyvinylidene fluoride (PVDF) membrane (Millipore, Billerica MA, USA), HRPconjugated secondary antibodies (Sigma, St. Louis, MO, USA), $\beta$-actin (Sigma, St. Louis, MO, USA). 


\section{Plant material}

Fresh, disease-free leaves of $A$. precatorius were collected from Danvantrivanna, Bangalore University campus, Bangalore, Karnataka, India. The plant material was identified and authenticated by an expert taxonomist. The collected plant material was brought to the laboratory, washed thoroughly under running tap water in order to remove dirt, germs and other contaminants, shade dried then powdered and used for extractation. An authenticated voucher specimen of the plant (BU/MKSMDNBL/AP-1) was deposited in the herbarium of Molecular Diagnostics and Nanobiotechnology Laboratories, Department of Microbiology and Biotechnology, Bangalore University, Bangalore for future reference.

\section{Preparation of extract and solvent fractionation}

Aqueous leaf extracts of $A$. precatorius was prepared by the process of maceration. Dried plant sample was suspended in double distilled water at the rate of $10 \mathrm{gms}$ in $100 \mathrm{ml}$, sonicated for $15 \mathrm{~min}$ and mixed with a magnetic stirrer for overnight. The extract was filtered through two layered cheesecloth. The collected filtrate was further partitioned successively into five solvent fractions by separating funnel starting from water, hexane, chloroform, ethyl acetate and butanol (21). The partitioning scheme was shown in (fig. 1). Finally, all the five fractions were dried under reduced pressure, dissolved in DMSO and subjected to cytotoxic activity assay.

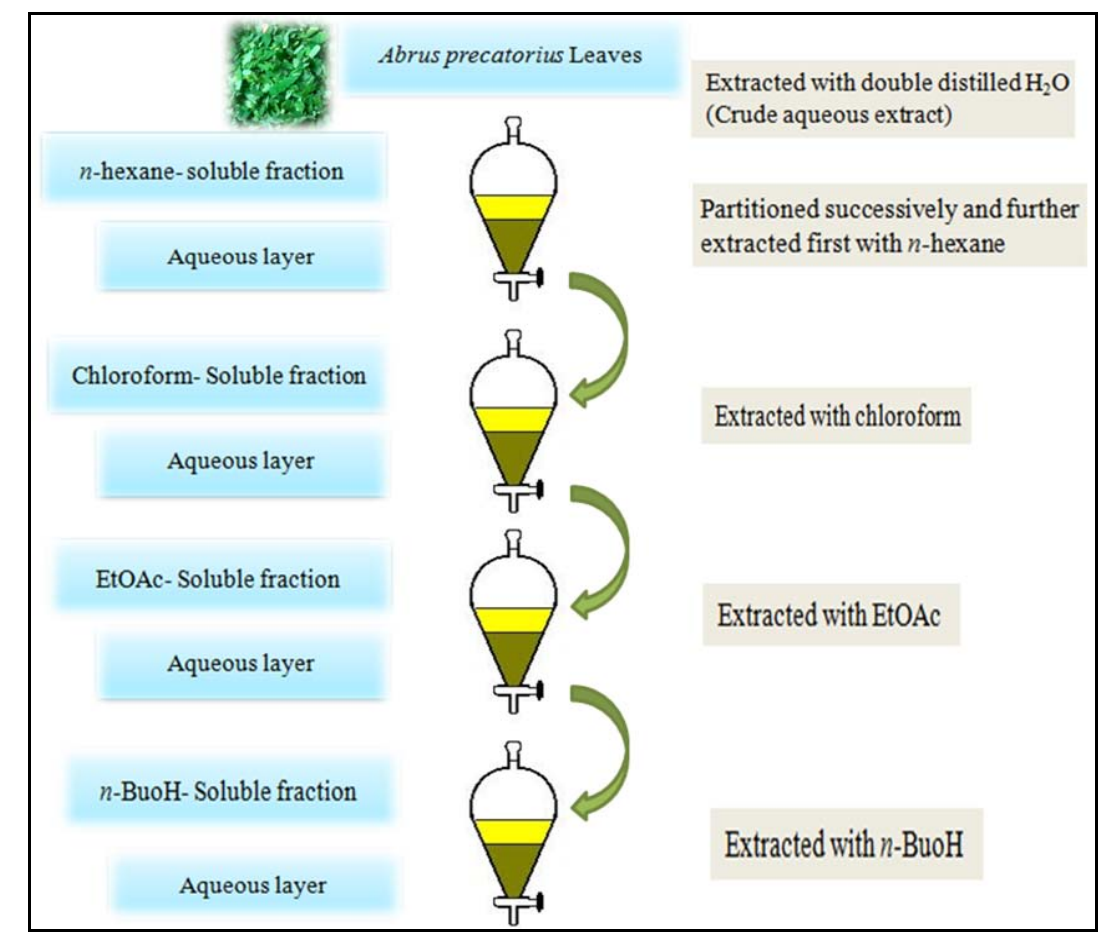

Fig. 1: Partitioning scheme of water, hexane, chloroform, ethyl acetate and butanol fractions obtained from the A. precatorius leaf extract

\section{Culturing of MDA-MB-231 cells}

Human breast cancer cell line MDA-MB-231 were obtained from American Type Culture Collection (ATCC), which was maintained in Dulbecco's Modified Eagle's medium (DMEM) with 10\% FBS, 100 $\mathrm{U} / \mathrm{ml}$ penicillin and $100 \mu \mathrm{g} / \mathrm{ml}$ streptomycin, in a humidified atmosphere of $95 \%$ air and $5 \% \mathrm{CO}_{2}$ at $37^{\circ} \mathrm{C}$. Cells were treated with the extract once the culture would reach around $80 \%$ confluence.

MTT (3, 4, 5-dimethylthiazol-2-yl)-2-5-diphenyl tetrazolium bromide) assay

MTT method was used to evaluate the cytotoxic activity of the EAFAP [22]. MTT assay was extensively used for quantifying cell death that was based on the capacity of mitochondrial enzymes of viable cells to reduce the yellow soluble salt MTT to purple-blue insoluble formazan precipitate which was quantified spectrophotometrically [23]. After $24 \mathrm{~h}$ cells were treated with different concentrations of EAF-AP for the specified time interval. $20 \mu \mathrm{l}$ of MTT $(5 \mathrm{mg} / \mathrm{ml})$ reagent was added to each well and then incubated for $3 \mathrm{~h}$ at $37^{\circ} \mathrm{C}$ in $\mathrm{CO}_{2}$ incubator. After $3 \mathrm{~h}$ medium was removed and $200 \mu \mathrm{L}$ of DMSO to solubilize formazan was added and mixed. Absorbance was recorded at $595 \mathrm{~nm}$ with a multiwell plate reader.

\section{Cell cycle analysis}

Cell cycle analysis was performed by propidium iodide (PI) based measurements of DNA content of the cells by flow cytometry. Cells were plated in a six-well plate at the rate of $4 \times 10^{5}$ cells per ml and incubated for $24 \mathrm{~h}$. Cells were treated with EAF-AP for another $24 \mathrm{~h}$ at its IC $\mathrm{I}_{50}$ value of $47.3 \mu \mathrm{g} / \mathrm{ml}$. The treated cells were trypsinized, washed with DPBS and fixed with $70 \%$ cold methanol and the mixture was kept in $-20^{\circ} \mathrm{C}$ overnight. The cells were centrifuged for $5 \mathrm{~min}$ at $2000 \mathrm{rpm}$ at $4^{\circ} \mathrm{C}$, the pellet was treated with $2 \mathrm{mg} / \mathrm{ml}$ RNAse-A at $37{ }^{\circ} \mathrm{C}$ and stained with $50 \mu \mathrm{g} / \mathrm{ml}$ propidium iodide. The sample was then subjected to FACS analysis and the percentage of cells in each stage of the cell cycle was determined using Cell-Quest software (Becton Dickinson, CA, USA).

\section{Western blot analysis}

The cells were seeded in a 6 well plate and incubated for $24 \mathrm{~h}$. The cells were treated with EAF-AP at its IC 50 concentration $(42.7 \mu \mathrm{g} / \mathrm{ml})$. For immunoblot analysis, total cell lysates were collected in lysis buffer (50 mmol HEPES-KOH, pH 7.5, 1\% Triton X-100, $150 \mathrm{mmol} \mathrm{NaCl}$ ) and protease inhibitor cocktail. The extracts were centrifuged at 12,000 rpm for $10 \mathrm{~min}$ and then the clear supernatant was collected. The protein content was determined by Bradford method. Proteins $(100 \mu \mathrm{g})$ were resolved on $10 \%$ sodium dodecyl sulphate (SDS)-polyacrylamide gel and electrotransferred to polyvinylidene fluoride (PVDF) membrane (Immunobilon-P, $0.45 \mu \mathrm{m}$ ). The membranes were blocked with $5 \%$ $(\mathrm{w} / \mathrm{v})$ non-fat dry milk and the membranes were incubated with specific antibodies to PARP (1:1000 dilution) and Caspase-3 (1:2000 dilution) overnight at $4{ }^{\circ} \mathrm{C}$. Blots were then washed with TBST and incubated with HRP-conjugated secondary antibodies. Detection of proteins was then performed by using femto-lucent substrate and X-ray film. $\beta$-actin was used as an internal control. 


\section{Caspase-3 activity assay}

The cells were placed in a six-well plate and then treated with EAFAP for $24 \mathrm{~h}$ at $47.3 \mu \mathrm{g} / \mathrm{ml}$ concentration. After treatment individual cells were trypsinized to make a single cell suspension and neutralized with spend media. Fluorescein isothiocyanate (FITC) conjugated (Z-VAD-FMK) (Promega, Madison, USA) was diluted in the ratio $0.5 \mu \mathrm{l}$ in $250 \mu \mathrm{l}$ of the complete medium. Cells without FITC were kept as control. Both treated and control cells were incubated for $90 \mathrm{~min}$ in a $\mathrm{CO}_{2}$ incubator with intermittent mixing. After the incubation period, the cells were centrifuged at $3000 \mathrm{rpm}$ for $5 \mathrm{~min}$. The pellet was then re-suspended in $0.3 \mathrm{ml}$ of washing buffer. The cells were kept on ice and taken for FACS analysis.

\section{Gene expression analysis by semi-quantative RT-PCR}

Total RNA was extracted from the cells by Trizol ${ }^{\circledR}$ reagent according to the manufacturer's protocol. After extraction, total RNA was quantified by measuring absorbance using a nano-drop. Before performing reverse transcription, RNA was treated with $10^{-5} \mathrm{U}$ deoxyribonuclease I (DNase-I) for $30 \mathrm{~min}$ at $37{ }^{\circ} \mathrm{C}$. DNase-I treated RNA was reverse transcribed by ABI Reverse Transcription kit following the manufacturer's protocol. The cDNA equivalent to $20 \mathrm{ng}$ of total RNA was used for PCR reactions. For expression analysis, gene-specific primers as listed in (table 1) were used. RPL35a (a ribosomal protein coding RNA) was used as an internal control and PCR products were analyzed on $1 \%$ agarose gels.

Table 1: Primer sequences of $p 53, p 21, B A X, B c l-2$ and Rpl35a genes

\begin{tabular}{|c|c|c|c|}
\hline S. No. & Gene & Amplicon size & Primer sequence \\
\hline 1. & p53 & 146bps & RT-FORWARD:-GCTCGACGCTAGGATCTGAC RT-REVERSE:-CAGGTAGCTGCTGGGCTC \\
\hline 2. & $p 21$ & $140 \mathrm{bps}$ & RT-FORWARD:-GCCATTAGCGCATCACAGT \\
\hline 3. & $B A X$ & $108 \mathrm{bp}$ & RT-REVERSE:-ACCGAGGCACTCAGAGGAG \\
\hline 4. & Bcl-2 & $141 \mathrm{bp}$ & RT-FORWARD:-GGAGGAAGTCCAATGTCCAG \\
\hline \multirow[t]{5}{*}{5.} & Rpl35a & 141bps & RT-REVERSE:-TCTGACGGCAACTTCAACTG \\
\hline & & & RT-FORWARD:-CCAGAGGAGGAGGTAGGGAC \\
\hline & & & RT-REVERSE:-TGATGTGAGTCTGGGCTGAG \\
\hline & & & RT-FORWARD:-CTGGTTTTGTTTGGTTTGCC \\
\hline & & & RT-REVERSE:-AAGGGAGCACACAGCTCTTC \\
\hline
\end{tabular}

\section{Statistical analysis}

The data represent the mean \pm SD of three independent experiments each in a triplicate. The significance between control and treated groups was analysed by student's t-test and $p$ values less than 0.05 were taken as significant by GraphPad Prism 5.0 software (GraphPad Software Inc., CA, USA).

\section{RESULTS}

\section{MTT assay for cytotoxicity}

Among the five fractions of $A$. precatorius, only ethyl acetate fraction of $A$ precatorius (EAF-AP) shows significant cytotoxic activity in a dosedependent manner on MDA-MB-231 cells (fig. 2a). Other four fractions did not show much cytotoxic activity, suggesting that the active cytotoxic compounds of $A$. precatorius leaf extract are fractionated in an ethyl acetate fraction only. Treatment of MDA-MB-231 cells for $48 \mathrm{~h}$ with an EAF-AP showed a very significant and higher cytotoxic activity with an $\mathrm{IC}_{50}$ value of $47.3 \mu \mathrm{g} / \mathrm{ml}$ (fig. $2 \mathrm{~b}$ ). These results indicated that EAF-AP has a potent cytotoxic activity on MDA-MB-231 breast cancer cells.

\section{Morphological studies}

Microscopic examination of MDA-MB-231 cells treated with EAF-AP showed significant morphological changes such as shrinkage and detachment from the surface (fig. 3). Owing to the loss of cells, differences in the cell number can also be visualized in a culture dish, when it was treated with EAF-AP for $48 \mathrm{~h}$ in comparison to the control dish. These results show that $A$. precatorius has a potent cytotoxic activity on breast cancer cells.

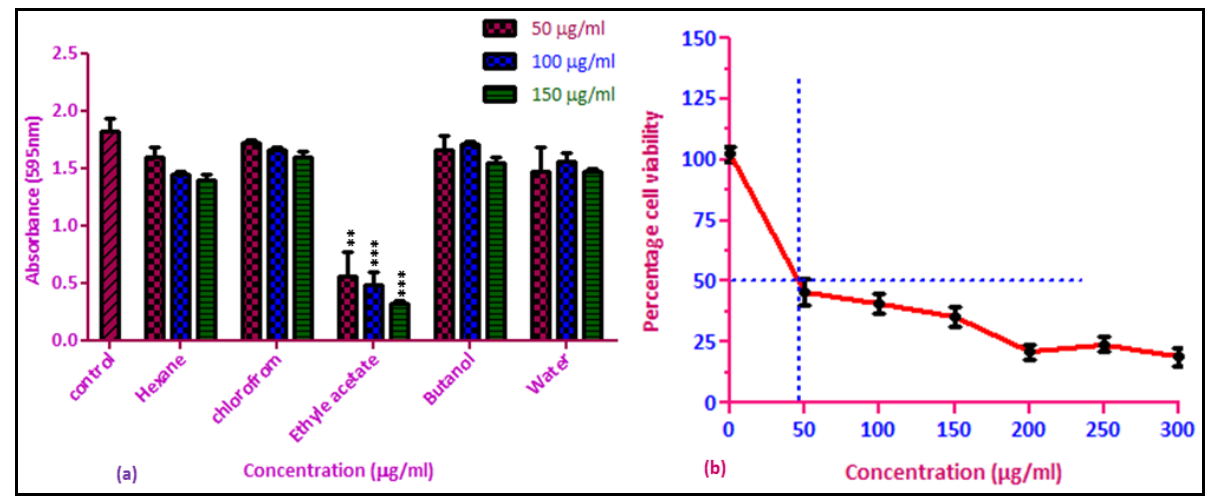

Fig. 2: Cytotoxic activity of various solvent fractions on MDA-MB-231 cells (a) ethyl acetate fraction of $A$. precatorius (EAF-AP) showed significant cytotoxic activity at concentration $(50-150 \mu \mathrm{g} / \mathrm{ml})$ after $48 \mathrm{~h}$ of treatment (b) Dose dependent cytotoxic activity of EAF-AP on MDA-MB-231 cells was observed, with an $\mathrm{IC}_{50}$ value of $47.3 \mu \mathrm{g} / \mathrm{ml}$. Values are mean \pm SEM of at least three independent experiments, each in triplicates. Values are mean \pm SEM of at least three independent experiments, each in triplicates. Significant cytotoxic activity $(p$ value $\leq$ 0.05 ) between the groups

\section{Cell cycle analysis}

As EAF-AP has a potent cytotoxic activity on MDA-MB-231 cells, it was necessary to investigate the nature of cell death in these cells. FACS analysis is conventionally performed to assess whether a compound induces cell cycle arrest or apoptosis in a cell. As shown in fig. 4, FACS analysis indicates that treatment of MDA-MB-231 cells with EAF-AP induces apoptosis in these cells. A significant increase (from $11.8 \%$ to $53.46 \%$ ) in sub G0/G1 population of cells is observed upon treatment with EAF-AP in comparison to contro cells (table 2). Further, not much change in the cell population of Sphase or G2 was observed, suggesting that EAF-AP may not have a cytostatic activity. These results show that EAF-AP has a proapoptotic activity on MDA-MB-231 cells. 


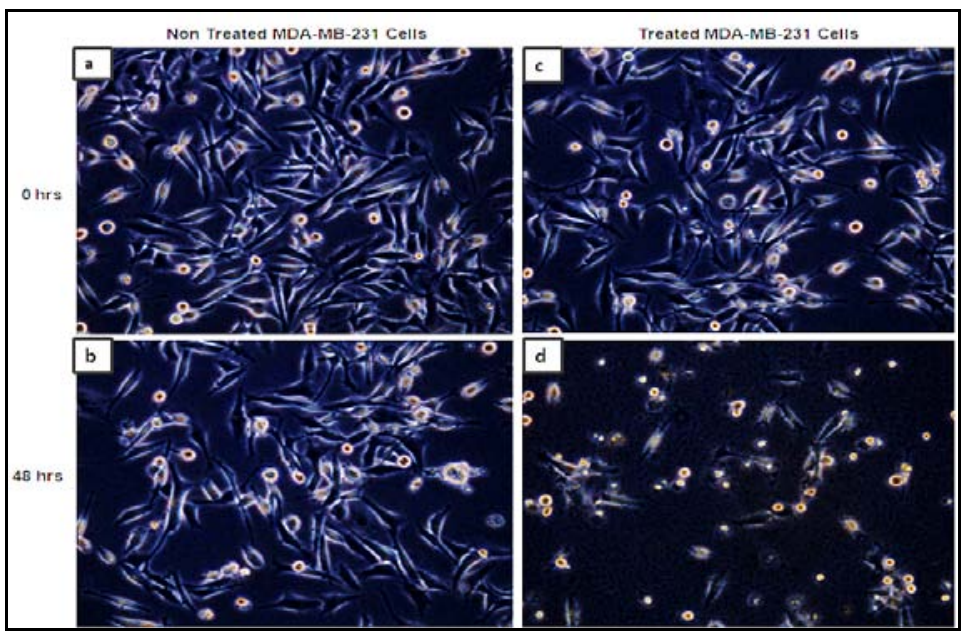

Fig. 3: Microscopic view of human breast cancer MDA-MB-231 cells (10X magnification) (a) Non-treated control cells at $0 \mathrm{~h}$ and (b) $48 \mathrm{~h}$; (c) Treated cells at $0 \mathrm{~h}$ and (d) $48 \mathrm{~h}$ at with $\mathrm{IC}_{50}$ concentration $(47.3 \mu \mathrm{g} / \mathrm{ml})$

Table 2: Percentage of cells in the different stages of the cell cycle after treatment with $A$. precatorius extract

\begin{tabular}{lll}
\hline Cell cycle stage & MDA-MB-231 Cells (\%) & \\
\cline { 2 - 3 } & Non treated & EAF-AP treated \\
\hline G1 (M1) & $61.53 \pm 5$ & $23.91 \pm 3$ \\
S (M2) & $10.48 \pm 2$ & $13.26 \pm 1$ \\
G2 M (M4) & $4.27 \pm 2$ & $4.47 \pm 2$ \\
Apoptotic (Sub-G0-G1) (M1) & $11.8 \pm 2$ & $53.46 \pm 8$ \\
\hline
\end{tabular}

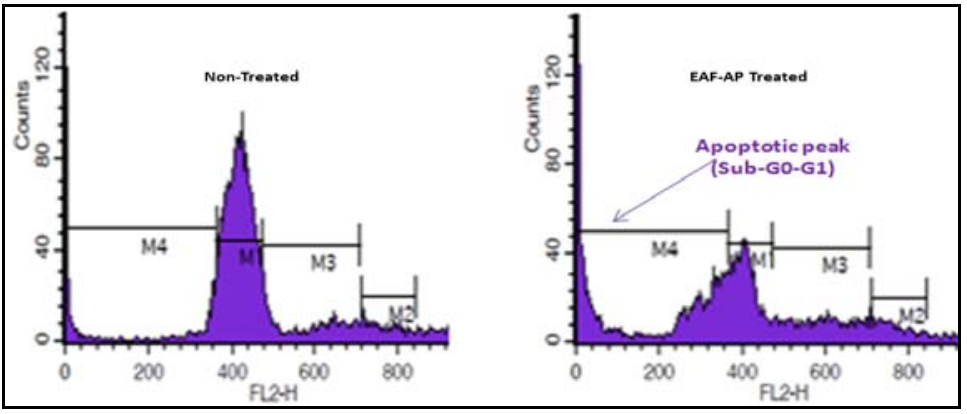

Fig. 4: Cell cycle phase analysis by flow cytometry in MDA-MB-231 cells treated with $A$. precatorius extract. Histograms show a number of cells (vertical axis) vs. DNA content (horizontal axis). A notable increase in the sub-G0/G1 population can be seen in the treated sample

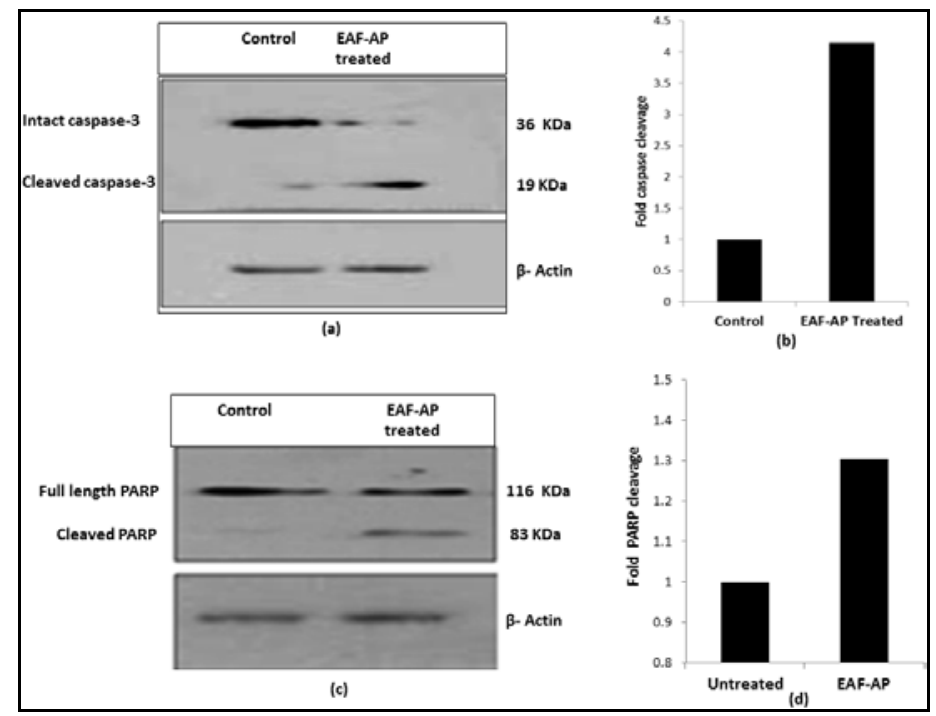

Fig. 5: Cleavage of caspase-3 and inactivation of PARP in MDA-MB-231 treated cells (a) Western blot and (b) densitometry of western blot bands. (c) PARP cleavage and (d) relative fold change of PARP cleavage 


\section{Western blot analysis}

When a cell undergoes apoptosis, caspase- 3 gets cleaved that leads to its activation. Western blotting analysis was performed to analyze cleavage and the activation of caspase-3 upon EAF-AP treatment of MDA-MB-231 cells. Treatment of MDA-MB-231 cells with EAF-AP results in proteolytic cleavage of caspase- 3 as revealed by the appearance of $19 \mathrm{kDa}$ cleaved fragment of caspase-3 (fig. 5a). The densitometry analysis of the western blot indicated 4 fold increase in cleavage of caspase-3 upon treatment with EAF-AP (fig. 5b). Activation of caspases leads to degradation of several target proteins and enzymes involved in cell cycle progression and DNA repair. A well-known target of caspases is PARP; an enzyme involved in repairing the DNA damage in a cell. Western blot analysis shows that EAF-AP treatment of MDA-MB-231 cells leads to cleavage and hence inactivation of PARP. This was revealed by the appearance of $83 \mathrm{kDa}$ cleaved fragment of PARP in the western blot (fig. 5c). The densitometric analysis indicated around 1.33 fold increase in the cleavage of PARP upon treatment with EAF-AP in MDA-MB-231 cells (fig. 5d).

\section{Caspase- 3 activity assay}

To confirm the activation of Caspase-3, fluorescence-based caspglow assay was also performed. Flow cytometric analysis shows that the treatment of MDA-MB-231 cells with EAF-AP results in a significant shift in the peak towards the right, suggesting activation of caspase-3 (fig. 6.). The fluorescence intensity shift was recorded from $1.76 \%$ (control cells) to $54.27 \%$ (treated cells). The result shows that EAF-AP treatment leads to cleavage and activation of caspase-3 in MDA-MB-231 cells.

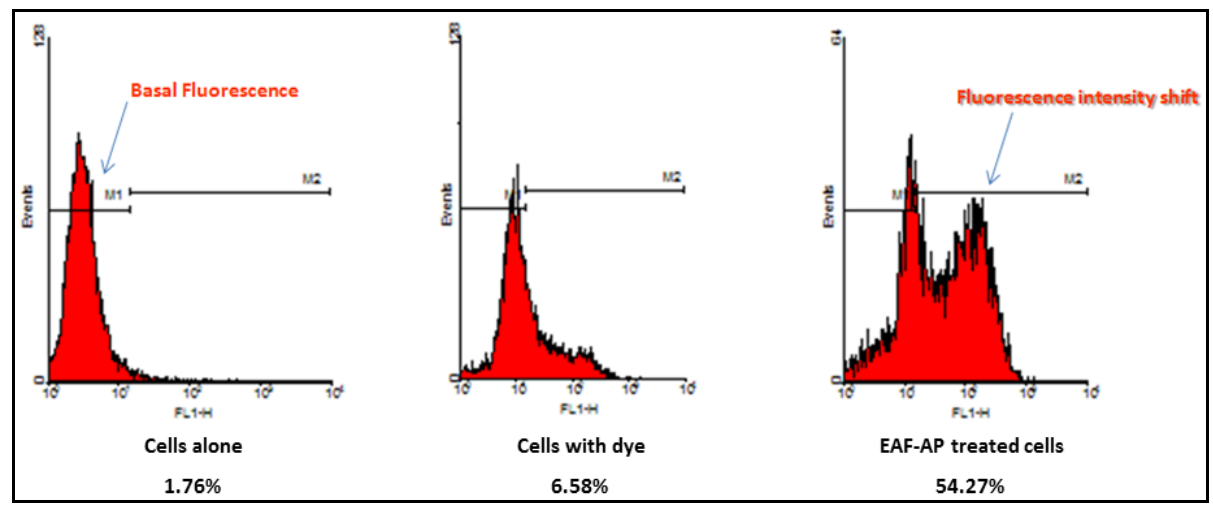

Fig. 6: Fluorescence-based Casp-glow assay shows activation of caspase-3 in MDA-MB-231. In comparison to control cells, a shift towards the right in the peak is observed in cells treated with $A$. precatorius extract

\section{Gene expression analysis by semi-quantative RT-PCR}

Semi-quantative RT-PCR analysis revealed a significant upregulation of pro-apoptotic genes $p 53, p 21$ and Bax when treated with EAF-AP for $24 \mathrm{~h}$ (fig. 7a). In addition, down-regulation of antiapoptotic gene $\mathrm{Bcl}-2$ was also observed. The graphs below shows the quantitation of the change in expression levels of the respective genes (fig. 7b). Treatment of MDA-MB-231 cells with EAF-AP leads to approximately 3.5 fold up-regulation in $p 53,4.7$ fold upregulation in $p 21$ and 2.2 fold up-regulation in Bax gene expression level. Likewise, 1.61 fold down-regulation of anti-apoptotic gene $B c l$ 2 was observed in EAF-AP treated MDA-MB-231 cells. These results indicated that EAF-AP leads to a change in the expression of various cell cycle regulators and hence affects the survival of these cells.

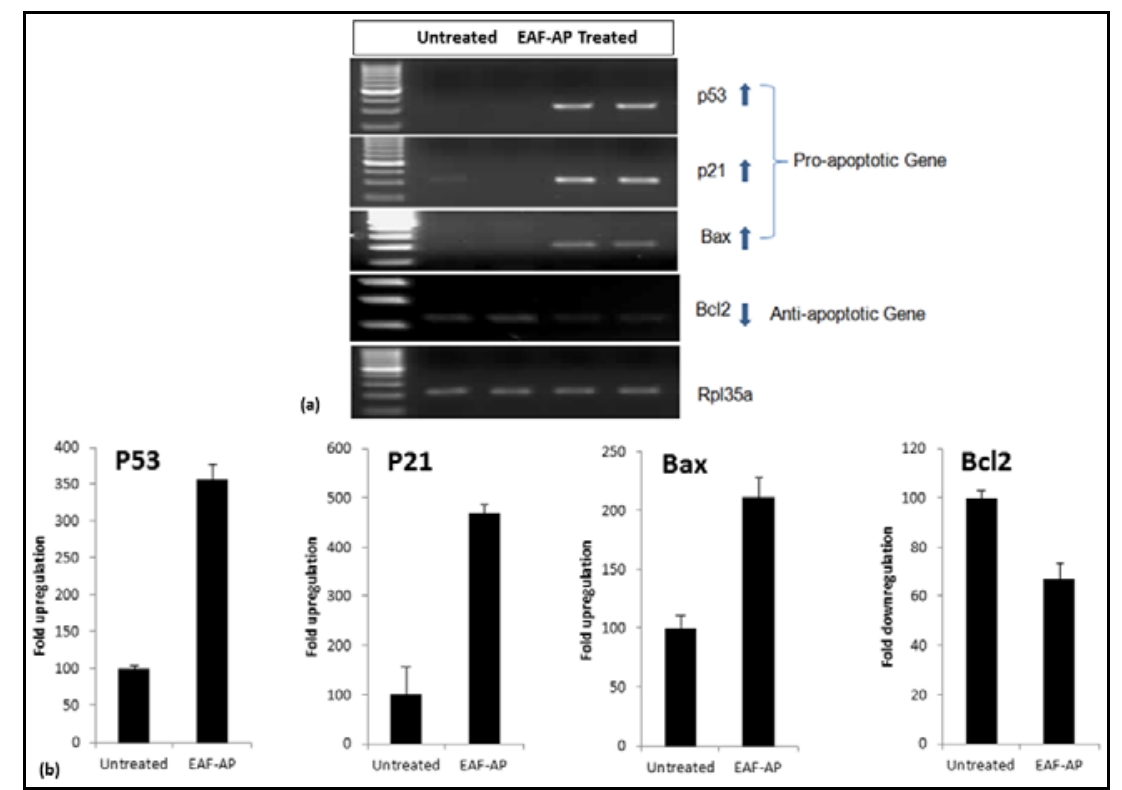

Fig. 7: Expression analysis of various pro-apoptotic and anti-apoptotic genes by PCR in treated and untreated MDA-MB-231 cells with $A$. precatorius extract (a) Lane $1=100$ bp marker; Lane $2,3=$ cells without treatment; Lane 4-5= cells treated with $A$. precatorius extract at $(47.3 \mu \mathrm{g} / \mathrm{ml})$ for $24 \mathrm{~h}$. Rpl35a (a ribosomal protein coding RNA) as an internal control (b) Respective graphs show quantitation of the RT PCR band 


\section{DISCUSSION}

Medicinal plants are candidates for chemoprevention of cancer because they possess chemopreventive agents with inhibitory effects on the initiation, promotion and progression of carcinogenesis. For these reasons, plants have always been an important source of drugs and are still playing a rapidly increasing role in the lead-finding of drug candidates for the development of chemotherapeutic agents [24; 25]. In order to identify and characterize the active cytotoxic compounds in leaf extract of $A$. precatorius, the aqueous fraction was further fractionated into five different solvent fractions. In the present investigation, for the first time, it was demonstrated that EAF-AP strongly inhibits the growth of MDA-MB-231 cells, with an $\mathrm{IC}_{50}$ value of $47.3 \mu \mathrm{g} / \mathrm{ml}$. More than $90 \%$ of cell death was achieved at higher concentrations after $48 \mathrm{~h}$ of treatment. Earlier studies had shown that various plant extracts and phytocompounds isolated from medicinal plants have shown significant cytotoxic and apoptotic activity on different cancer cell lines [26]. Treated cells showed prominent morphological changes due to a dose-dependent inhibition of cells proliferation. Also to understand the exact molecular mechanism behind cell death, various apoptotic assays were performed. Most of the cytotoxic anticancer drugs in current use have been shown to induce apoptosis in susceptible cells $[27 ; 28]$. To gain insights into the mechanism by which cell reduction was achieved, the effect on cell cycle distribution by FACS analysis was done. Flow cytometric analysis showed that $A$. precatorius has a pro-apoptotic activity on MDA-MB-231 cells. Cell cycle analysis by flow cytometer exhibited a sub-G0/G1 peak in EAF-AP treated MDA-MB-231 cells. As compared to control, treated cells showed an accumulation of cells in G0/G1 phase and thus inhibited the transition of cells into $S$ phase, followed by increases in the proportion of cells in the sub-G1 phase. This increase of cells in sub-G1 was taken to reflect the induction of apoptosis. The agents that alter the cell cycle have been of particular interest since cell cycle regulation was the basic mechanism underlying cell fate, i.e. proliferation, differentiation or apoptosis [29]. These results are in accordance with the previous results [30, 31].

Further, activation of caspase- 3 was involved in the induction of apoptosis upon EAF-AP treatment of MDA-MB-231 cells. Caspase are molecules that play a central role in the process of apoptosis. Caspases get activated upon a signal, which in turn act on their target molecules finally leading to cell death. Caspase-3 is a very important key of apoptosis and has been recognized as crucial executioner caspase responsible for the activation and cleavage of over 100 substrates that finally will lead to DNA fragmentation and apoptosis. Caspase-3 cleavages DNA repair enzyme, poly-ADP-ribose polymerase (PARP) that finally will lead to DNA fragmentation and apoptosis [34]. Both caspase-3 and PARP are considered as significant markers of cells undergoing apoptosis. In this study, both of these markers showed positive alteration in the EAF-AP treated cells. Western blotting results clearly indicated cleavage of caspase3 and PARP, which are the main indications of activation of caspase3 and deactivation of PARP important mediators of apoptosis. Activation of caspase-3 was further confirmed by casp-glow assay by flow cytometry. Consistent with this result, various previous studies indicated phytochemicals induced apoptosis in cancerous cells through the activation of caspase- 3 and PARP cleavage [35].

Cell cycle and apoptosis involve several regulators and mediators. Under normal conditions, cells divide and express these regulators and mediators at a steady state level. However, upon various stress conditions, cell cycle progression will be halted and various inhibitors of cell cycle progression are induced. If the damage is not repaired, then the cells will undergo apoptosis under normal conditions [37]. The p53 tumour-suppressor is one such critical regulator of cellular response to DNA damage and apoptosis. EAF-AP treatment leads to the up-regulation of $p 53$ in addition to other cell cycle regulators $p 21$ and Bax. The balance between apoptotic and anti-apoptotic genes are known to be important in determining whether cells die or survive [38]. The results also show a downregulation of anti-apoptotic gene $B c l-2$, upon treatment of MDA-MB231 cells with EAF-AP. All these studies suggest that EAF-AP treatment leads to the induction of apoptosis in MDA-MB-231 cells.
Some of the dietary agents that are also known to modulate apoptotic genes include curcumin, resveratrol, EGCG, indole-3carbinol and silibinin [39]. EAF-AP is known to consist of cytotoxic compounds that are very effective against metastatic breast cancer MDA-MB-231 cells.

\section{CONCLUSION}

All these results suggest that EAF-AP acts as an effective pharmacological agent in treating breast cancer. Further, this data will help in the isolation, identification and characterization of the specific anticancer bioactive principle present in EAF-AP that are mainly responsible for the activity. In conclusion, it can be inferred that $A$. precatorius possess a profound anticancer activity and hence provide an alternative option for breast cancer treatment.

\section{AUTHORS CONTRIBUTIONS}

Dr Mohammad Shafi Sofi is the main author of the whole manuscript, all the experiment and statistical analysis were done by Dr Mohammad Shafi Sofi.

\section{CONFLICTS OF INTERESTS}

\section{Declared none}

\section{REFERENCES}

1. Weinberg RA. Oncogenes and the molecular biology of cancer. J Cell Biol 1983;97:1661-2.

2. Bertram JS. The molecular biology of cancer. Mol Aspects Med 2001;21:167-223.

3. Grimm M, Cetindis M, Lehmann M, Biegner T, Munz A, Teriete $\mathrm{P}$, et al. Association of cancer metabolism-related proteins with oral carcinogenesis-indications for chemoprevention and metabolic sensitizing of oral squamous cell carcinoma. J Transl Med 2014;12:208.

4. Globocan. Estimated cancer incidence, mortality and prevalence worldwide in International Agency for Research on Cancer (IARC); 2012.

5. World Health Organization. World Cancer Report. The International agency for research on cancer (IARC), Geneva; 2014.

6. Ahmedin J, Rebeca S, Elizabeth W, Yongping H, Xu J, Michael JT. Cancer statistics. CA Cancer J Clin 2009;59:225-49.

7. World Health Organization. Cancer incidence and mortality worldwide. The International agency for research on cancer (IARC), Geneva; 2008.

8. Brody JG, Rudel RA. Environmental pollutants and breast cancer. Environ Health Persp 2003;111:1007-19.

9. Moorthi C, Kumar CS, Kathiresan K. Synergistic anti-cancer activity of curcumin and bio-enhancers combination against various cancer cell lines. Int J Pharm Pharm Sci 2014;6:901-3.

10. Altmann KH, Gertsch J. Anticancer drugs from nature-natural products as a unique source of new microtubule-stabilizing agents. Nat Prod Rep 2007;24:327-57.

11. Surekha R, Deshpande SNB. Cytotoxicity of stem extracts of selected cassia species against Hela and breast cancer cell lines in vitro. Asian J Pharm Clin Res 2017;10:80-2.

12. Cragg GM, Newman J. Nature: a vital source of leads for anticancer drug development. Phytochem Rev 2009;8:313-31.

13. Upur H, Yusup A, Baudrimont I, Umar A, Berke B, Yimit D, et al. Inhibition of cell growth and cellular protein, DNA and RNA synthesis in human hepatoma (HepG2) cells by ethanol extract of abnormal Savda Munziq of traditional Uighur medicine. Evid Based Complement Alternat Med 2011:1-9. http://dx.doi.org/ 10.1093/ecam/nen062

14. Nadkarni KM. Indian Materia Medica. Popular Prakashan Bombay, India; 1976.

15. Adedapo AA, Omoloye OA, Ohore OG. Studies on the toxicity of an aqueous extract of the leaves of $A$. precatorius in rats. Onderstepoort J Vet Res 2007;74:31-6.

16. Dnyaneshwar JT, Ravindra YP. Effect of A. precatorius leaves on milk induced leukocytosis and eosinophilia in the management of asthma. Asian Pac J Trop Med 2012;1:40-2.

17. Shih SF, Wu YH, Hung CH, Yang HY, Lin JY. Abrin triggers cell death by inactivating a thiol-specific antioxidant protein. J Biol Chem 2001;276:21870-7. 
18. Narayanan S, Surolia A, Karande AA. Ribosome-inactivating protein and apoptosis: abrin causes cell death via the mitochondrial pathway in Jurkat cells. Biochem J 2004;377:233-40.

19. Bhutia SK, Mallick SK, Maiti TK. In vitro immunostimulatory properties of Abrus lectins derived peptides in tumor-bearing mice. Phytomedicine 2009;16:776-82.

20. Mojarrab M, Lagzianb MS, Emamic SA, Asilic J, Najaranb ZT. In vitro antiproliferative and apoptotic activity of different fractions of Artemisia armeniaca. Rev Bras Farmacogn 2013;23:783-8.

21. Mosmann T. Rapid colourimetric assay for cellular growth and survival: application to proliferation and cytotoxicity assays. J Immunol Methods 1983;16:55-63.

22. Plumb JA. Cell sensitivity assays: the MTT assay. Methods Mol Med 2004;88:165-9.

23. Schwartsmann G. Marine organisms and other novel natural sources of new cancer drugs. Ann Oncol 2000;11:235-43.

24. Lall RK, Syed DN, Adhami VM, Khan MI, Mukhtar H. Dietary polyphenols in the prevention and treatment of prostate cancer. Int J Mol Sci 2015;16:3350-76.

25. Polachi N, Nagaraja P, Subramaniyan B, Mathan G. Antiproliferative activity of n-butanol floral extract from Butea monosperma against Hct 116 colon cancer cells; drug-likeness properties and in silico evaluation of their active compounds toward glycogen synthase kinase-3 $\beta /$ axin and $\beta$-catenin/t-cell factor-4 protein complex. Asian J Pharm Clin Res 2015;8:13441.

26. Christopher SP. The significance of spontaneous and induced apoptosis in the gastrointestinal tract of mice. Cancer Metast Rev 1992;11:179-95.

27. Antony E, Sathiavelu M, Arunachalam S. Synthesis of silver nanoparticles from the medicinal plant Bauhinia acuminata and Biophytum sensitivum-a comparative study of its biological activities with plant extract. Int J Appl Pharm 2017;9:22-9.
28. Dobashi Y, Takehana T, Ooi A. Perspectives on cancer therapy: cell cycle blockers and perturbators. Curr Med Chem 2003;10:2549-58.

29. Zeytinoglu H, Incesu Z, Baser KH. Inhibition of DNA synthesis by carvacrol in mouse myoblast cells bearing a human N-RAS oncogene. Phytomedicine 2003;10:292-9.

30. Kim DI, Lee SJ, Lee SB, Park K, Kim WJ, Moon SK. The requirement for Ras/Raf/ERK pathway in naringin induced G1 cell cycle arrest via p21WAF1 expression. Carcinogenesis 2008;29:1701-9.

31. Kanzawa T, Germano IM, Komata T, Ito H, Kondo Y, Kondo S. Role of autophagy in temozolomide-induced cytotoxicity for malignant glioma cells. Cell Death Differ 2004;11:448-57.

32. Kim H, Yong JM, Seok AK, Cho SK. Quercetin induces mitochondrial-mediated apoptosis and protective autophagy in human glioblastoma U373MG cells. Oxid Med Cell Longev 2013;596496:1-10

33. Soldani C, Scovassi AI. Poly (ADP-ribose) polymerase-1 cleavage during apoptosis: an update. Apoptosis 2002;7:321-8.

34. Jin CY, Park C, Cheong J, Choi BT, Lee TH, Lee JD, et al. Genistein sensitizes TRAIL-resistant human gastric adenocarcinoma AGS cells through activation of caspase-3. Cancer Lett 2007;257:56-64.

35. Daniel RC, Bernand WS. Etoposide-induced cytotoxicity in two human T-cell leukaemic lines: delayed loss of membrane permeability rather than DNA fragmentation as an indicator of programmed cell death. Cancer Res 1993;53:4887-96.

36. Vogelstein B, Kinzler KW. p53 function and dysfunction. Cell 1992;70:523-6.

37. Korsmeyer SJ, Shutter JR, Veis DJ, Merry DE, Oltvai ZN. Bcl2/Bax: a rheostat that regulates an antioxidant pathway and cell death. Sem Cancer Biol 1993;4:327-32.

38. Aggarwal F, Conforti G, Ioele GA, Statti M, Marrelli Ragno G, Menichini F. Antiproliferative activity against human tumor cell lines and toxicity test on Mediterranean dietary plants. Food Chem Toxicol 2008;46:3325-32. 